\title{
Chelated minerals and two limestone particle sizes on production of layers in the second laying cycle
}

\author{
Minerais quelatados e duas granulometrias de calcário sobre a produção de poedeiras \\ em segundo ciclo produtivo
}

\author{
SOUSA, Alisson Melo de ${ }^{1 *}$; BASTOS-LEITE, Silvana Cavalcante ${ }^{1}$; GOULART, \\ Cláudia de Castro $^{1}$; BARROSO, Maria Luana da Silva ${ }^{1}$; SILVA, Josefa Deis Brito ${ }^{1}$
}

\author{
${ }^{1}$ Universidade Estadual Vale do Acaraú, Centro de Ciências Agrárias e Biológicas, Departamento de \\ Zootecnia, Sobral, Ceará, Brasil. \\ *Endereço para correspondência: alisson.zoot@gmail.com
}

\section{SUMMARY}

The aim of this experiment was to evaluate the performance, egg quality, and bone quality of commercial white-egg layer hens in the second production cycle fed diets containing organic and inorganic minerals and two limestone particle sizes. A total of 215 birds with an average weight of $1.527 \pm 0.092 \mathrm{~kg}$ were distributed in a completely randomized design in a $2 \times 2$ factorial arrangement (two mineral sources and two limestone particle sizes) with six replicates. The following four treatments were tested: $\mathrm{T} 1=$ inorganic minerals $+100 \%$ fine limestone; $\mathrm{T} 2=$ inorganic minerals $+50 \%$ fine limestone $+50 \%$ coarse limestone; $\mathrm{T} 3=$ organic minerals $+100 \%$ fine limestone; and $\mathrm{T} 4$ $=$ organic minerals $+50 \%$ fine limestone $+50 \%$ coarse limestone. No significant interaction occurred between the studied factors for any variable. Egg production, egg mass, bone resistance and bone deformity were higher with organic supplementation. Eggshell weight, percentage of eggshell, and specific gravity were higher in the treatments with the fine+coarse limestone association. In conclusion, organic mineral supplementation improves the performance based on egg production and egg mass. The association between fine and larger-sized limestone improves the external quality of eggs. The use of organic minerals improves the bone quality of birds in the second production cycle.

Keywords: bone quality, calcium sources, egg laying, mineral supplementation, organic mineral

\section{RESUMO}

Neste experimento objetivou-se de avaliar o desempenho, qualidade dos ovos e qualidade óssea das poedeiras comerciais leves em $2^{\circ}$ ciclo de produção, submetidas às dietas contendo minerais orgânicos e inorgânicos e duas granulometrias do calcário. Foram utilizadas 216 aves, com peso médio de $1,527 \pm 0,092 \mathrm{~kg}$, distribuídas em um delineamento inteiramente casualizado em um esquema fatorial 2 X 2 (duas fontes de minerais e duas granulometrias do calcário), com seis repetições. Foram empregados quatro tratamentos a seguir: $\mathrm{T} 1=$ minerais inorgânicos $+100 \%$ de calcário fino; T2 = minerais inorgânicos $+50 \%$ de calcário fino $+50 \%$ de calcário grosso; $\mathrm{T} 3=$ minerais orgânicos $+100 \%$ de calcário fino e T4 = minerais orgânicos $+50 \%$ de calcário fino $+50 \%$ de calcário grosso. Não houve interação significativa entre os fatores estudados para nenhuma variável. A produção de ovos, massa de ovo, resistência e deformidade óssea foram melhores com a suplementação orgânica. $\mathrm{O}$ peso da casca, percentagem da casca e a gravidade específica foram melhores nos tratamentos com a associação do calcário fino + grosso. Concluiu-se que suplementação mineral orgânica melhora o desempenho com base na produção de ovos e massa dos ovos. A utilização da associação do calcário fino com o de maior granulometria melhora a qualidade externa dos ovos. A utilização de minerais orgânicos melhora a qualidade óssea das aves, em $2^{\circ}$ ciclo produtivo.

Palavras-chave: fontes de cálcio, mineral orgânico, postura, qualidade óssea, suplementação mineral 


\section{INTRODUCTION}

The egg production scenario in the poultry industry has shown some substantial evolution in the last few years, as a consequence of the enhancement of techniques of management, sanitation, nutrition, automation of facilities, and genetic breeding, resulting in increasingly precocious and productive lines. However, despite this evolution, there is a concern about the maintenance of the eggshell quality and the bone structure of layers during the productive cycle, aiming to reduce economic losses due to the egg calcification. In this regard, supplementation of minerals is a necessary practice because of their participation in important biochemical processes that are essential to the growth and development of the bird, especially the processes of bone tissue growth and the egg formation (BRITO et al., 2006). The use of trace minerals in organic form relatively to the conventional forms has been emphasized, based on the assumption that they can be easily absorbed by birds, improving their egg laying life span. Regarding the participation of minerals in the physiological processes, they act in the activation of several enzymes in the eggformation process (ARAUJO et al., 2008).The trace minerals zinc, magnesium, and copper act on bone growth and development (NUNES et al., 2013).

Chelated minerals are more easily retained and absorbed by birds (FIGUEIREDO JÚNIOR et al., 2013), improving their performance and reducing environmental contamination by the lower excretion of minerals (NOLLET et al., 2007) that are potentially pollutant. However, research results are still controversial (BRITO et al., 2006).

Nutritional deficiencies in layers can lead to a reduction of productivity and low egg shell quality occurring a frequently mobilization of bone calcium (ALMEIDA PAZ et al., 2009). Thus, a good uptake of dietary calcium is recommended for birds in the laying period, because it is targeted towards the egg calcification. In addition to the dietary calcium level, questions have emerged about the particle size of the calcium source utilized. In this context, it is arguing that limestone particles should be large enough to be retained in the gizzard of the birds for a longer period, allowing the release and absorption of calcium (AMERAH et al., 2008).

Therefore, this study was conducted aiming to evaluate the effect of organic minerals and two particle size of limestone on the productive performance, egg quality, and bone quality of commercial layers in the second production cycle.

\section{MATERIAL AND METHODS}

The experiment was conducted in the poultry section of the Experimental Farm at UVA, located in Sobral - CE, Brazil. The experimentation animal protocol of number $\mathrm{n}^{\mathrm{o}} 00212$ was approved by the Institutional Committee of Ethics on Animal Use CEUA/UVA. A total of 216 Hy-Line White layer hens with an average weight of $1.512 \pm 0.051 \mathrm{~kg}$, at 88 weeks of age, were used in the experiment. The experimental period was 112 days, divided into four 28-day periods. A completely randomized experimental design was adopted, in a $2 \times 2$ factorial 
arrangement, with six replicates of nine birds.

The birds were subjected to forced molting by the feed-deprivation method, according to the procedures indicated in the manual of the line (HY LINE DO BRASIL, 2011).

The experimental diets were formulated according to the requirements suggested by Rostagno et al. (2011) as shown in Table 1.

The following treatments were employed: $\mathrm{T} 1=$ inorganic minerals $(\mathrm{Fe}$,
$\mathrm{Cu}, \mathrm{Zn}, \mathrm{Mn}, \mathrm{I}, \mathrm{Se})+$ and $100 \%$ fine limestone; $\mathrm{T} 2$ = inorganic minerals + $50 \%$ fine limestone $+50 \%$ coarse limestone; $\mathrm{T} 3=$ organic minerals $(\mathrm{Cu}$, $\mathrm{Mn}$, and $\mathrm{Zn}$; and the other minerals in inorganic form) $+100 \%$ fine limestone; and $\mathrm{T} 4=$ organic minerals $+50 \%$ fine limestone $+50 \%$ coarse limestone. As to the particle size, the samples were classified, based on the geometric diameter (GDM), as fine (GDM 0.35 $\mathrm{mm}$ ) and coarse (GDM 2,790 mm).

Table 1. Centesimal and calculated nutritional composition of the experimental diet

\begin{tabular}{lcccc}
\hline \multirow{2}{*}{ Ingredient } & \multicolumn{3}{c}{ Quantity (\%) } \\
\cline { 2 - 5 } & $\mathrm{T} 1$ & $\mathrm{~T} 2$ & $\mathrm{~T} 3$ & $\mathrm{~T} 4$ \\
\hline Corn grain & 59.750 & 59.750 & 59.750 & 59.750 \\
Soybean meal (45\%) & 27.182 & 27.182 & 27.182 & 27.182 \\
Soybean oil & 1.502 & 1.502 & 1.502 & 1.502 \\
Dicalcium phosphate & 1.105 & 1.105 & 1.105 & 1.105 \\
Fine limestone & 9.539 & 4.769 & 9.539 & 4.769 \\
Coarse limestone & - & 4.769 & - & 4.769 \\
Common salt & 0.523 & 0.523 & 0.523 & 0.523 \\
Methionine & 0.0613 & 0.0613 & 0.0613 & 0.0613 \\
Egg-laying premix 0.4\% 500TEC** & 0.4 & 0.4 & - & - \\
Egg-laying premix 0.4\% QLT* & - & - & 0.4 & 0.4 \\
\hline \multicolumn{2}{l}{ Calculated nutritional composition } & & & \\
\hline Metabolizable energy (kcal/kg) & 2.800 & 2.800 & 2.800 & 2.800 \\
Crude protein (\%) & 17 & 17 & 17 & 17 \\
Calcium (\%) & 4.02 & 4.02 & 4.02 & 4.02 \\
Available phosphorus (\%) & 0.3 & 0.3 & 0.3 & 0.3 \\
Sodium (\%) & 0.225 & 0.225 & 0.225 & 0.225 \\
Total methionine + cystine (\%) & 0.98 & 0.98 & 0.98 & 0.98 \\
Total methionine (\%) & 0.739 & 0.739 & 0.739 & 0.739 \\
Total lysine (\%) & 0.812 & 0.812 & 0.812 & 0.812 \\
\hline
\end{tabular}

* 7278 - Egg-laying premix II 0.4\% QLT (Chelated), ${ }^{1}$ Mineral-vitamin supplement per kg of organic premix: copper amino acid chelate: $2,500.00 \mathrm{mg} / \mathrm{kg}$; manganese amino acid chelate: 30,000.00 mg; calcium iodate: $250.00 \mathrm{mg}$; zinc aminoacid chelate: $25,000.00 \mathrm{mg}$; ferrous sulfate: $12,500.00 \mathrm{mg}$; cobalt sulfate: $25.00 \mathrm{mg}$; sodium selenite: $75.00 \mathrm{mg}$; vitamin A: 2,000,000.00 IU; vitaminD3: 750,000.00 IU; vitamin E: 3,000.00 mg; vitamin K3: $500.00 \mathrm{mg}$; vitamin B1: $250.00 \mathrm{mg}$; vitamin B2: $1,250.00 \mathrm{mg}$; niacin: 5,000.00 mg; pantothenic acid: $1,750.00 \mathrm{mg}$; vitaminB6: $500.00 \mathrm{mg}$; folic acid: $100.00 \mathrm{mg}$; biotin: $5.00 \mathrm{mg}$; vitamin B12: 3,000.00 mcg; cholinechloride: 100,000.00 mg; methionine: 125,000.00 mg; colistin sulfate: $1,750.00 \mathrm{ppm}$.

**7422 - PX POSTURA $0.4 \% 500$ TEC (Inorganic), ${ }^{2}$ Mineral-vitamin supplement per kg of organic premix: ferrous sulfate: $10.00 \mathrm{~g}$; copper sulfate: 2,500.00 $\mathrm{mg}$; zinc sulfate: $25.00 \mathrm{~g}$; manganêse monoxide: $20.00 \mathrm{~g}$; calcium iodate: $208.00 \mathrm{mg}$; sodium selenite: $75.00 \mathrm{mg}$; vitamin A: 1,750,000.00 IU; vitamin D3: 625,000.00 IU; vitamin E: 2,000.00 mg; vitamin K3: $395.00 \mathrm{mg}$; folic acid: $74.00 \mathrm{mg}$; choline: $75.00 \mathrm{~g}$; niacin: 5,025.00 mg; pantothenic acid: $1,805.00 \mathrm{mg}$; vitamin B1: $250.00 \mathrm{mg}$; vitamin B2: $1,000.00 \mathrm{mg}$; vitamin B6: $250.00 \mathrm{mg}$; vitaminB12: $2,400.00 \mathrm{mcg}$; methionine: $125.00 \mathrm{~g}$; colistin: $1.750 .00 \mathrm{ppm}$. 
The premixes utilized in the study were two distinct commercial products. The premix with organic minerals contained only the following three chelated minerals: copper amino acid chelate, manganese amino acid chelate, and zinc amino acid chelate; all the other minerals were in inorganic form.

Intake and egg-production data were recorded throughout the experiment, to obtain the data of performance variables. These parameters were feed intake (g/bird/day), egg production (\%), egg weight (g), egg mass (g/bird/day), conversion per egg mass $(\mathrm{kg} / \mathrm{kg})$, and conversion per dozen eggs $(\mathrm{kg} / \mathrm{dz})$.

At the end of every 28-day period, four eggs were collected per replicate for the analyses of egg quality, in which the percentages of albumen, yolk, and shell, in addition to shell thickness (mm), egg specific gravity $\left(\mathrm{g} / \mathrm{cm}^{3}\right)$, broken and cracked eggs (\%) were evaluated.

At the end of the experiment, one bird was chosen at random per replicate, identified, and sacrificed by cervical dislocation. After the sacrifice, the drumsticks and thighs were removed and stored in a freezer at $-20^{\circ} \mathrm{C}$, where they remained until the moment of deboning.

For the deboning, the pieces were removed from the freezer and left to thaw on the platforms until they reached room temperature. Subsequently, the drumsticks and thighs were immersed in boiling water for ten minutes, and then deboned following the method described by Bruno (2002).

To evaluate bone quality, only the tibiae were used. The bone length was measured using a caliper, and the weight was obtained using an electronic scale with $0.01 \mathrm{~g}$ precision. Bone density was evaluated by the Seedor index, calculated by dividing the weight $(\mathrm{mg})$ by the length $(\mathrm{mm})$ of the evaluated bone (SEEDOR et al., 1991).
Analyses of bone resistance and bone deformity were conducted in the Laboratory of Soil Mechanics at the Department of Transportation Engineering at the Federal University of Ceará, using a mechanical press. The bones (left tibiae) were placed horizontally, with their extremities on a wooden platform, and then a compression force was applied on the center of each bone. The maximum strength applied on the bone to its breakage was considered the tensile strength $\left(\mathrm{kgf} / \mathrm{cm}^{2}\right)$, which was measured by a digital strain gauge. The deformity ( $\mathrm{mm}$ ) was measured using an analogical strain gauge up to the breakage of the bone.

The ash content was determined at the Laboratory of Animal Nutrition (LANUT) of UVA. After deboning, the tibiae (right side) were weighed and dried in a forced-air oven at $105^{\circ} \mathrm{C}$ for $72 \mathrm{~h}$. Next, they were ground with a mortar and a pestle. Ground samples were conditioned in labeled plastic bags for later determination of the mineral matter (MM) content, according to the method described by Silva \& Queiroz (2002).

The statistical analyses of the data were performed using the software Statistical Analysis System (SAS, 2000), adopting $5 \%$ as the significance level. The data were subjected to analysis of variance (ProcAnova, SAS), and subsequently to a factorial model, in which the effects of treatments, mineral sources, and limestone particle size, and the interaction between the factors were included. Means were compared by Tukey's test.

\section{RESULTS AND DISCUSSION}

No significant interaction was observed $(\mathrm{P}>0.05)$ between the studied factors for any of the performance variables (Table 2). Likewise, no significant effect 
$(\mathrm{P}>0.05)$ of the types of mineral supplements or particle size of limestone was observed on the variables feed intake, egg weight, and conversion per egg mass and per egg dozen (Table 2).

The egg-production and egg-mass parameters were influenced by the mineral supplements, with the best results provided by organic supplementation. These results are assumed to be related to the bioavailability of the chelated minerals, because they are more easily absorbed and retained by the birds, which may bring benefits to performance like the above mentioned (KIEFER, 2005). The results are similar to those observed by Figueiredo Júnior et al. (2013), who studied the effect of organic mineral levels on the performance of layers and found increased production and egg mass compared with inorganic sources.

Table 2. Feed intake (FI), egg production (EP), average egg weight (AEW), egg mass (EM), and feed conversion per egg mass (FCEM) and per dozen eggs (FCDZ) of commercial layers in the 2 nd production cycle fed diets with inorganic or organic minerals and two limestone particle sizes

\begin{tabular}{lcccccc}
\hline Treatment & $\begin{array}{c}\text { FI } \\
(\mathrm{g} / \mathrm{bird} / \text { day })\end{array}$ & EP $(\%)$ & $\begin{array}{c}\text { AEW } \\
(\mathrm{g})\end{array}$ & $\begin{array}{c}\text { EM } \\
(\mathrm{g} / \text { bird/day })\end{array}$ & $\begin{array}{c}\text { FCEM } \\
(\mathrm{kg} / \mathrm{kg})\end{array}$ & $\begin{array}{c}\text { FCDZ } \\
(\mathrm{kg} / \mathrm{kg})\end{array}$ \\
\hline Mineral source & & & & & & \\
\hline Inorganic & 90.75 & $73.52^{\mathrm{B}}$ & 70.88 & $52.15^{\mathrm{B}}$ & 1.734 & 1.471 \\
Organic & 89.16 & $77.88^{\mathrm{A}}$ & 70.87 & $55.22^{\mathrm{A}}$ & 1.650 & 1.402 \\
\hline Limestone & & & & & & \\
\hline Fine & 89.41 & $75.71^{\mathrm{a}}$ & 71.15 & $53.91^{\mathrm{a}}$ & 1.667 & 1.452 \\
Fine + Coarse & 90.50 & $75.68^{\mathrm{a}}$ & 70.59 & $53.46^{\mathrm{a}}$ & 1.717 & 1.421 \\
Mean & 89.95 & 75.70 & 70.87 & 53.68 & 1.692 & 1.437 \\
SEM & 0.58 & 0.62 & 0.27 & 0.44 & 0.016 & 0.013 \\
\hline AnalysisVariance & & & & & & \\
\hline Mineral source (MS) & 0,2601 & 0,0024 & 0,9927 & 0,0095 & 0,0992 & 0,0667 \\
Limestone (L) & 0,4344 & 0,9814 & 0,4240 & 0,6816 & 0,3132 & 0,4027 \\
MS x L & 0,8584 & 0,5373 & 0,6366 & 0,4533 & 0,7439 & 0,8375 \\
\hline
\end{tabular}

Working with organic minerals on the performance of brown-egg layers in the second production cycle, Saldanha et al. (2009) also did not observe differences in percentage of eggs, or feed conversion per $\mathrm{kg}$ and dozen eggs, corroborating the results found in the present study. However, Maciel et al. (2010) observed a greater egg weight, higher specific weight and lower percentage of egg loss of commercial laying hens at the end of laying and concluded that benefits are obtained with inclusion of $50 \%$ zinc, manganese and copper in organic form.

Better results were expected for intake with the treatments that involved the association with the limestone particles, because older birds prefer larger particles (SCOTTÁ et al., 2014), and when they ingest these they also consume the smaller feed particles, improving their intake as a whole, which did not occur in the present study. Similar results were reported by Saunders-Blades et al. (2009), who stated that the particle size of the 
calcium source does not significantly influence feed intake, and consequently performance, since birds fed diets with different limestone particle sizes consume enough nutrients for good performance.

No significant interaction was observed between the studied factors for any of the egg-quality variables. Thus, likewise, no effect of the two mineral sources and particle sizes was detected on the variables percentage of albumen, percentage of yolk, shell thickness, broken eggs, and cracked eggs. However, the variables percentage of eggshell, and egg specific gravity were influenced by the limestone particle sizes (Table 3).

Table 3. Percentage of albumen (PA), percentage of yolk (PY), percentage of eggshell (PE), shell thickness (ST), specific gravity (SG), broken eggs (BE), and cracked eggs (CE) of commercial layers in the 2nd production cycle fed diets with inorganic or organic minerals and two limestone particle sizes

\begin{tabular}{lccccccc}
\hline Treatment & PA (\%) & PY (\%) & PE (\%) & $\begin{array}{c}\text { ST } \\
(\mathrm{mm})\end{array}$ & $\begin{array}{c}\text { SG } \\
\left(\mathrm{g} / \mathrm{cm}^{3}\right)\end{array}$ & BE (\%) & $\begin{array}{c}\text { CE } \\
(\%)\end{array}$ \\
\hline Inorganic mineral & 61.66 & 26.20 & $8.76^{\mathrm{A}}$ & 0.371 & $1.085^{\mathrm{A}}$ & 1.78 & 1.30 \\
Organic mineral & 61.55 & 26.05 & $8.59^{\mathrm{A}}$ & 0.367 & $1.084^{\mathrm{A}}$ & 1.98 & 1.35 \\
Fine limestone & 61.96 & 25.96 & $8.47^{\mathrm{b}}$ & 0.364 & $1.082^{\mathrm{b}}$ & 1.98 & 1.32 \\
Fine + Coarse limestone & 61.24 & 26.29 & $8.88^{\mathrm{a}}$ & 0.373 & $1.086^{\mathrm{a}}$ & 1.79 & 1.32 \\
Mean & 61.60 & 26.13 & 8.67 & 0.369 & 1.084 & 1.88 & 1.32 \\
SEM & 0.17 & 0.16 & 0.05 & 0.02 & 0.004 & 0.05 & 0.07 \\
\hline AnalysisVariance & & & & & & & \\
\hline Mineral source (MS) & 0,7973 & 0,7359 & 0,0715 & 0,4798 & 0,4722 & 0,1882 & 0,5081 \\
Limestone (L) & 0,0985 & 0,4631 & 0,0108 & 0,0742 & 0,0001 & 0,1975 & 0,9417 \\
MS x L & 0,4208 & 0,9296 & 0,2230 & 0,5141 & 0,7501 & 0,2457 & 0,7294 \\
\hline
\end{tabular}

Considering the reduction of calcium retention as the birds age, the obtained results were presumably due to the solubility and larger particle size of this mineral retained in the mechanical stomach (gizzard), which allowed the calcium to be utilized at night, during the period of formation of the eggshell, when the layers cease to consume the feed.

This finding corroborates Ito et al. (2006), who concluded that the use of limestone with mixed or coarse particle sizes improves eggshell quality.

Opposite results were found by Jardim Filho et al. (2005), who did not observe the effect of limestone particle size on the eggshell quality of layers during the period of peak production. Likewise,
Murata et al. (2009) concluded that the associates of limestone powder with limestone gravel did not have an effect on the studied parameters; these authors worked with calcium levels and limestone particle sizes on the quality of eggs from layers in the first cycle.

Although organic mineral sources have higher availability, providing better performance when consumed, in the present study no improvement was detected regarding the internal or external egg quality. In the literature, the results for the use of chelated minerals are highly controversial as to the improvement of shell quality and internal egg quality. This fact can be explained by the quantity of several chelated molecules present and 
their differences in bioavailability and stability as well as their metabolism (SECHINATO et al., 2006).

No significant interaction between the studied factors was found on the bonerelated variables analyzed in this study.
The bone resistance and deformity parameters were influenced significantly by the mineral supplements, with the best results obtained by organic supplementation (Table 4).

Table 4. Seedor Index (SI), bone resistance (BR), bone deformity (BD), and tibia ash (ASH) of commercial layers in the 2nd production cycle fed diets with inorganic or organic minerals and two limestone particle sizes

\begin{tabular}{lcccc}
\hline Treatment & $\begin{array}{c}\mathrm{SI} \\
(\mathrm{mg} / \mathrm{mm})\end{array}$ & $\mathrm{BR}\left(\mathrm{kg} / \mathrm{cm}^{2}\right)$ & $\mathrm{BD}(\mathrm{mm})$ & ASH $(\%)$ \\
\hline Inorganic mineral & 66.39 & $5.32^{\mathrm{B}}$ & $2.45^{\mathrm{B}}$ & 48.28 \\
Organic mineral & 67.34 & $7.15^{\mathrm{A}}$ & $3.37^{\mathrm{A}}$ & 49.88 \\
Fine limestone & 67.36 & $6.22^{\mathrm{a}}$ & $2.89^{\mathrm{a}}$ & 50.59 \\
Fine + Coarse limestone & 66.26 & $6.36^{\mathrm{a}}$ & $2.99^{\mathrm{a}}$ & 48.84 \\
Mean & 66.88 & 6.28 & 2.93 & 49.59 \\
SEM & 0.98 & 0.34 & 0.09 & 0.82 \\
\hline AnalysisVariance & & & & 0,7331 \\
\hline Mineral source (MS) & 0,7088 & 0,0110 & 0,0001 & 0,2328 \\
Limestone (L) & 0,6714 & 0,8294 & 0,5644 & 0,9257 \\
MS x L & 0,1546 & 0,5324 & 0,1074 & \\
\hline
\end{tabular}

Concerning the better results obtained for bone resistance and deformity in the treatments with organic supplementation, it is assumed that these results are due to the bioavailability of the chelated minerals, because they are more easily absorbed and retained by the birds (BRITO et al., 2006), and so they may bring benefits to bone quality such as the abovementioned examples.

Results similar to those found in the present study for bone resistance were reported by Nunes et al. (2013), working with increasing levels of $\mathrm{Cu}$, $\mathrm{Mn}, \mathrm{Zn}$, and $\mathrm{Fe}$ proteinates for brownegg layers in the period of 30 to 70 weeks of age. Brito et al. (2006), working with organic and inorganic minerals in diets for replacement pullets aged 7 to 12 weeks, reported that the treatments did not influence the ash content of the birds' tibia, which are similar results to those obtained in this experiment.

Oliveira et al. (2013), working with increasing levels of coarse limestone in diets for white-egg layers, reported that the limestone particle sizes did not influence the Seedor Index. These results are similar to those obtained in the current study.

In conclusion, the supplementation with organic minerals improves the performance and bone quality based on egg production, egg mass, bone resistance, and bone deformity. The association between fine and coarse limestone improves the external quality of eggs from layer hens in the second production cycle. 


\section{REFERENCES}

ALMEIDA PAZ, I.C.L.; MENDES, A.A.; BALOG, A.; KOMIYAMA, C.M.; TAKAHASHI, S.E.; ALMEIDA, I.C.L.; GARCÍA, E.A.; VULCANO, L.C.; BALLARIN, A.W.; SILVA, M.C.; CARDOSO, K.F.G. Efeito do cálcio na qualidade óssea e de ovos de poedeiras. Archivos de Zootecnia, v.58, n.222, p.173-183, 2009.

AMERAH, A.M.; RAVINDRAN, V.; LENTLE, R.G.; THOMAS, D.G. Influence of feed particle size on the performance, energy utilization, digestive tract development, and digesta parameters of broilerstarters fed wheatand corn-based diets. Journal Poultry Science [online], v.87, n.11, p.2320 2328, 2008.

ARAUJO, J.A. de; SILVA, J.H.V. da; AMÂNCIO, A.L. de L.; LIMA, C.B.; OLIVEIRA, E.R.A. de. Fontes de minerais para poedeiras. Acta

Veterinaria Brasilica [online], v.2, n.3, p.53-60, 2008.

BRITO, J.Á.G. de I; BERTECHINI, A.G.; FASSANI, É.J.;RODRIGUES, P.B.; FONSECA, R.T. de F. Uso de microminerais sob a forma de complexo orgânico em rações para frangas de reposição no período de 7 a 12 semanas de idade. Revista Brasileira de Zootecnia [online], v.35, n.4, p.13421348, 2006.

\section{BRUNO, L.D.G. Desenvolvimento} ósseo em frangos: influência da restrição alimentar e da temperatura ambiente.2002. 77f. Tese (Doutorado em Zootecnia) - Faculdade de Ciências Agrárias e Veterinárias, Universidade Estadual Paulista, Jaboticabal.
FIGUEIREDO JÚNIOR, J.P.; COSTA, F.G.P.; GIVISIEZ, P.E.N.; LIMA, M.R.; SILVA, J.H.V.; FIGUEIREDOLIMA, D.F.; SARAIVA, E.P.; SANTANA, M.H.M. Substituição de minerais inorgânicos por orgânicos na alimentação de poedeiras semipesadas. Arquivo Brasileiro de Medicina Veterinária e Zootecnia [online], v.65, n.2, p.513-518, 2013.

\section{HY LINE DO BRASIL. Manual da}

linhagem: Poedeiras Comerciais HyLine W-36. 2011. Available at: $<$ http://www.hylinedobrasil.com.br/hyli ne/download/guia w36 E3.pdf.>. Accessed on: Nov. 23, 2013.

ITO, D.T.; FARIA, D.E.de; KUWANO, E.A.; JUNQUEIRA, O.M.; ARAUJO, L.F. de. Efeitos do fracionamento do cálcio dietário e granulometria do calcário sobre o desempenho e qualidade dos ovos de poedeiras comerciais. Acta Scientiarum. Animal Sciences [online], v.28, n.2, p.187-195, 2006.

JARDIM FILHO, R. de M., STRINGHINI, J.H., CAFÉ, M.B.; ANDRADE, M.A.; SAKAMOTO, M.I.; FRANCO, J.R.G. Influência das fontes e granulometria do calcário calcítico sobre a densidade, resistência e composição mineral da tíbia de poedeiras comerciais. Acta Scientiarum.Animal Sciences [online], v.27, n.1, p.23-28, 2005.

\section{KIEFER C. MINERAIS}

QUELATADOS NA NUTRIÇÃO DE AVES E SUIINOS Revista Eletrônica

Nutritime, v.2, n.3, p.206-220, 2005.

MACIEL, M.P.; SARAIVA, E.P.; AGUIAR, É. de F.; RIBEIRO, P.A.P.; PASSOS, D.P.; SILVA, J. Effect of using organic microminerals on performance and external quality of 
eggs of commercial laying hens at the end of laying. Revista Brasileira de Zootecnia [online], v.39, n.2, p.344348, 2010.

MURATA, L.S.; ARIKI, J.; SANTANA, A.P.; JARDIM FILHO,R. de M. Níveis de cálcio e granulometria do calcário sobre o desempenho e a qualidade da casca de ovos de poedeiras comerciais. Revista Biotemas [online], v.22. n.1, p.103-110, 2009.

NOLLET, L.; VAN DER KLIS, J.D.; LENSING, M.; SPRING, P. The effect of replacing inorganic with organic trace minerals in broiler diets on productive performance and mineral excretion. Journal of Applied Poultry Research [online], v.16, n.4, p.592-597, 2007.

NUNES, J.K.; SANTOS, V.L.; ROSSI, P.; ANCIUTI, M.A.; RUTZ, F.; MAIER, J.C.; SILVA, G.C. Qualidade de ovos e resistência óssea de poedeiras alimentadas com minerais orgânicos.

Arquivo Brasileiro de Medicina Veterinária e Zootecnia [online], v.65, n.2, p.610-618, 2013.

OLIVEIRA, A.N. de; FREITAS, E.R.; FILGUEIRA, T.M.B.; CRUZ, C.E.B.; NASCIMENTO, G.A.J. do. Limestone particle size and artificial light for laying hens in the second laying cycle.

\section{Revista Brasileira de Zootecnia} [online], v.42, n.7, p.481-488, 2013.

PELÍCIA, K.; GARCIA, E.A.; SCHERER, M.R.S.; MÓRI, C.; DALANEZI, J.A.; FAITARONE A.B.G.; MOLINO, A.B.; BERTO, D.A. Alternative calcium source effects on commercial egg production and quality. Brazilian Journal of Poultry Science [online], v.9, n.2, p.105-109. 2007.
ROSTAGNO, H.S.;ALBINO, L.F.T.; DONZELE, J.L.; GOMES, P.C.; OLIVEIRA, R.F. de; LOPES, D.C.; FERREIRA, A.S.; BARRETO, S.L. de $T$. Tabelas brasileiras para aves $\mathrm{e}$ suínos: composição de alimentos e exigências nutricionais. 3.ed. Viçosa: Universidade Federal de Viçosa, 2011. $252 \mathrm{p}$.

SALDANHA, E.S.P.B.; GARCIA, E.A.; PIZZOLANTE, C.C.; FAITTARONE, A.B.G.; SECHINATO, A. DA; MOLINO, A.B.; LAGANÁ, C. Effect of organic mineral supplementation on the egg quality of semi-heavy layers in their second cycle of lay. Revista Brasileira de Ciência Avícola [online], v.11, n.4, p.241-247, 2009.

SAUNDERS-BLADES, J.L.; MACISAAC, J.L.; KORVER, D.R.; ANDERSON, D.M. The effect of calcium source and particle size on the production performance and bone quality of laying hens. Journal Poultry Science [online], v.88, n.2, p.338-353, 2009.

SCOTTÁ, B.A.; CAMPOS, P.F.; GOMIDE, A.P.C.; BARROCA, C.C.; FORMIGONI, A. da S.; ZERLOTIN, M.F. Nutrição pré e pós-eclosão em aves. PUBVET [online], v.8, n.8, a.1702, 2014.

SECHINATO, A.S.; ALBUQUERQUE, R.; NAKADA, S. Efeito da suplementação dietética com micro minerais orgânicos na produção de galinhas poedeiras. Brazilian Journal Veterinary Research and Animal Science[ online], v.43, n.2, p.159-166, 2006. 
SEEDOR, J.G.; QUARTUCCIO, H.A.; THOMPSON, D.D.The biophosphanate alendronate (MK-217) inhibit bone loss due to ovariectomy in rats. Journal of Bone and Mineral Research [online], v.6, n.4, p.339-346, 1991.

SILVA, D.J.; QUEIROZ, A.C. Análise de alimentos: métodos químicos e biológicos. 3.ed. Viçosa, MG:

Universidade Federal de Viçosa, 2002. $167 \mathrm{p}$.

STATISTICAL ANALISYS SYSTEM - SAS. SAS/STAT: user's guide.

Version 7.0.Cary, 2000.325 p.

Data de recebimento: 11/12/2015

Data de aprovação: 23/01/2017 